\title{
Pankiller effect of prolonged exposure to menadione on glioma cells: potentiation by vitamin $\mathrm{C}$
}

\author{
Marina F. Vita $\cdot$ Nivedita Nagachar • \\ Dimitrios Avramidis • Zahid M. Delwar • \\ Mabel H. Cruz • Åke Siden • Kajsa M. Paulsson • \\ Juan Sebastian Yakisich
}

Received: 24 May 2010 / Accepted: 24 June 2010 / Published online: 13 July 2010

(C) The Author(s) 2010. This article is published with open access at Springerlink.com

Summary Menadione (Vitamin K3) has anti-tumoral
effects against a wide range of cancer cells. Its potential
toxicity to normal cells and narrow therapeutic range limit
its use as single agent but in combination with radiation or
other anti-neoplastic agents can be of therapeutic use. In
this paper, we first evaluated the early (within 3 h) effect of
menadione on ongoing DNA replication. In normal rat
cerebral cortex mini-units menadione showed an age
dependent anti-proliferative effect. In tissue mini-units
prepared from newborn rats, menadione inhibited ongoing

Marina F. Vita and Nivedita Nagachar contributed equally to this work.

M. F. Vita • D. Avramidis · Z. M. Delwar • M. H. Cruz •

Å. Siden · J. S. Yakisich $(\bowtie)$

Department of Clinical Neuroscience R54, Karolinska Institute, Karolinska University Hospital, Sweden Hospital,

14186 Huddinge, Stockholm, Sweden

e-mail: Sebastian.Yakisich@ki.se

K. M. Paulsson

Department of Experimental Immunology,

Institute of International Health, Immunology and Microbiology,

University of Copenhagen, Panum Institute,

Copenhagen, Denmark

N. Nagachar $\cdot$ K. M. Paulsson

Immunology Section, Lund University,

Lund, Sweden

Å. Siden

Department of Neurology, Karolinska University Hospital,

Stockholm, Sweden

Present Address:

M. F. Vita

Department of Microbiology, Tumor and Cell Biology (MTC),

Karolinska Institute,

Stockholm, Sweden
DNA replication with an IC ${ }_{50}$ of approximately $10 \mu \mathrm{M}$ but $50 \mu \mathrm{M}$ had no effect on mini-units from prepared adult rat tissue. The effect of short $(72 \mathrm{~h})$ and prolonged exposure (1-2 weeks) to menadione alone in the DBTRG.05MG human glioma cells line and in combination with vitamin $\mathrm{C}$ was studied. After short period of exposure data show that menadione alone or in combination with vitamin $\mathrm{C}$ provided similar concentration-response curves (and $\mathrm{IC}_{50}$ values). Prolonged exposure to these drugs was evaluated by their ability to kill $100 \%$ of glioma cells and prevent regrowth when cells are re-incubated in drug-free media. In this long-term assay, menadione:vitamin $\mathrm{C}$ at a ratio 1:100 showed higher anti-proliferative activity when compared to each drug alone and allowed to reduce each drug concentration between 2.5 to 5-fold. Similar antiproliferative effect was demonstrated in 8 patient derived glioblastoma cell cultures. Our data should be able to encourage further advanced studies on animal models to evaluate the potential use of this combination therapy for glioma treatment.

Keywords Gliomas · Menadione · Vitamin C · Proliferation $\cdot$ DNA replication

\section{Introduction}

Menadione (2-methyl-1, 4 naphthoquinone: vitamin $\mathrm{K}_{3}$ ) inhibits the growth of mammalian tumor cells both in vitro and in vivo, e.g. mouse or rat liver tumors, glioma, melanoma and neuroblastoma, cells [1,2], human glioma [3], hepatoma cells [4] and urologic tumors [5]. Moreover, a potentiation of radiotherapy by vitamin $\mathrm{K}$ has been shown [2] as well as a synergistic effect when given in combination with other anti-tumor agents [6]. Menadione 
has also effects on MDR1-expressing cancer cells both in culture and animal model systems [7]. It has been suggested that the cytotoxic effect of menadione is related to the generation of reactive oxygen species (ROS) by enzymatic reaction during its metabolism [8]. Menadione can generates ROS by non-enzymatic reaction with protein thiols in plasma [9]. Consistent with this observation, the thioldepleting agent N-ethylmaleimide (NEM) suppresses menadione-induced ROS generation and cytotoxicity to platelet. Menadione was also found to inhibit topoisomerase II [10], DNA polymerase gamma [11] and binds to tubulin, disrupting the microtubule networks [12]. Menadione, being a small lipid soluble molecule (M.W. 172.2 Da) is a potential drug for the treatment of brain tumors. As pointed out by Pardridge [13], only lipid soluble molecules with a molecular mass less than 400-600 Da are capable of crossing the blood brain barrier (BBB). The antiproliferative effect of menadione has been investigated in several glioma cell cultures using classical short term (2472) proliferation assays. In this type of assays, the concentration that inhibits proliferation by $50 \%\left(\mathrm{IC}_{50}\right)$ is the endpoint parameter usually measured. For most drugs, even at concentrations higher than the $\mathrm{IC}_{50}$, the short exposure time does not kill $100 \%$ of cells and the $\mathrm{IC}_{100}$ (or lethal concentration $100, \mathrm{LC}_{100}$ ) is calculated by interpolation. In most studies, the fate of surviving cells after short term incubation with drugs is not evaluated. For instance, glioma cells can survive prolonged exposure of antineoplastic drugs at concentrations much higher than the $\mathrm{IC}_{50}$ [14]. At the clinical level, these surviving cells explain the relapse of tumor when the treatment is discontinued and suggest that drugs that kill $100 \%$ of tumoral cells ("pankillers") will be more effective anti-cancer drugs and may, cure cancer. To circumvent this limitation, we recently postulated that long-proliferation assays and the determination of the minimum concentration and time necessary to kill cancer cells completely and prevent regrowth when the drug is removed from the culture (called Regrowth Concentration Zero, $\mathrm{RC}_{0}$ ) might help to improve the success of anti-cancer drugs entering clinical trials. In this study, we investigated the anti-proliferative effect of short and prolonged exposure of menadione on glioma cells. We found in the current study that menadione is an effective "pankiller" and its cytotoxic effect can be potentiated when used in combination with vitamin $\mathrm{C}$.

\section{Materials and methods}

\section{Reagents and enzymes}

Dimethylsulfoxide (DMSO), menadione and vitamin C were purchased from Sigma (Sweden). Dulbecco modified
Eagle's medium with glutamine and $4500 \mathrm{mg} / \mathrm{l} \mathrm{D}$-glucose (DMEM) and (Iscove's modified Dulbecco medium) IMDM were purchased from GIBCO/Life-technologies (Sweden). [methyl- ${ }^{3} \mathrm{H}$ ]-thymidine $(86.0 \mathrm{Ci} / \mathrm{mmol})$ was purchased from Amersham (U.K.). All other reagents were of analytical grade or the highest grade available.

\section{Cell lines}

Stock cultures of human DBTRG-05MG glioma cell line were obtained from the European Collection of Cell Culture (ECACC). Cells were routinely cultured as previously described [14]. Patients-derived glioblastoma cells hGCL1- hGCL8 were kindly provided by Dr Peter Siesjö (Lund University). The usage of patient glioblastoma multiforme tumor samples has been accepted by the Local Ethical Board of the University of Lund.

\section{Preparation of drugs}

Menadione was prepared as stock solutions $(100 \mathrm{mM})$ in DMSO and stored at $-20^{\circ} \mathrm{C}$. Vitamin $\mathrm{C}$ was diluted in distilated sterile water and stored at $-20^{\circ} \mathrm{C}$ as $500 \mathrm{mM}$ stock solution. The final dilutions were done in culture media, keeping the DMSO concentration below $1 \%(v / v)$.

\section{Experimental procedures}

\section{Determination of ongoing DNA replication}

Generation of tissue mini-units, determination of [methyl$3 \mathrm{H}$ ]-thymidine incorporation into DNA and ongoing DNA synthesis rate, protein quantitation and determination of effect of menadione were performed as previously reported $[15,16]$. Briefly, mini-units of normal rat cerebral tissue were generated immediately after killing the animals. These mini-units were then incubated in microwell plates (Nunc, Denmark) with DMEM containing $2 \mu \mathrm{Ci} / \mathrm{ml}$ [methyl-3H]thymidine and drugs at the appropriate concentration or their corresponding vehicle (DMSO or $\mathrm{H}_{2} \mathrm{O}$ ). Each experimental point was determined by at least quadruplicate. The DNA synthesis rate was calculated as $\mathrm{cpm} / \mathrm{mg}$ of protein/ min. The effect of drugs was determined as change (\%) of DNA synthesis rate compared to the corresponding control or percentage of control DNA synthesis rate. Animal experiments were approved by the Animal Ethical Committee at Huddinge University Hospital, Sweden.

Short term proliferation assay: Cell were plated in 96 well microplates $(\sim 5,000$ cell/well $)$ and allowed to adhere overnight. Drugs at the appropriate concentration were added and incubated for $72 \mathrm{~h}$. Cell viability was measured by the cell counting kit (CCK Kit) (Sigma, Sweden) following manufacturer's instructions. 
Long term proliferation assay: For prolonged effect of drugs on cell cultures, cells were plated in 96 well microplates $(\sim 5,000 \mathrm{cell} / \mathrm{well})$ and allowed to grow for $3-4$ days. Drugs were added and maintained for 2 weeks (media and drugs were changed twice a week). After 2 weeks, cells were incubated in drug-free media (changed twice a week) for 2-4 weeks. Regrowth was evaluated using a routine inverted microscope.

\section{Results}

Age dependent inhibition of DNA synthesis by menadione in normal rat cerebral cortex

The results obtained from tissue mini-units prepared from 5 days old rats showed a dose-dependent inhibition of the DNA synthesis in menadione treated mini-units $\left(\mathrm{IC}_{50} \cong\right.$ $10 \mu \mathrm{M})$ (Fig. 1a). This inhibitory effect was of short time onset as well as time-dependent since the inhibitory effect of $50 \mu \mathrm{M}$ menadione at 30 and $60 \mathrm{~min}$ were $34,66 \pm 2,90 \%$ and $84,36 \pm 2,25 \%$ respectively (data not shown). When tissue mini-units were prepared from adult rats ( $>60$ days old), menadione $(50 \mu \mathrm{M})$ failed to decrease the rate of DNA synthesis (Fig. 1b). When uptake experiments were performed (see "Materials and methods"), menadione $(50 \mu \mathrm{M})$ did not inhibit the cellular uptake of [methyl- $\left.{ }^{3} \mathrm{H}\right]$-thymidine prior to incorporation into DNA (Fig. 1c). Further, the reversibility of menadione effect on the incorporation [methyl $-{ }^{3} \mathrm{H}$ ]-thymidine into DNA showed that, a) 60 min of pre-incubation with menadione gave a strong $(84,36 \pm 2,25 \%)$ inhibition of DNA synthesis (Fig. 1d, grey columns), and b) removal of menadione from the medium failed to recover the capacity of the tissue to incorporate the radioactive precursor into DNA (Fig. 1d, black columns). In all cases, DMSO was used as control in concentrations below $1 \%(v / v)$ since it has been shown that DMSO at concentrations up to $1 \%(v / v)$ for $3 \mathrm{~h}$ has no effect on DNA synthesis rate.

Effect of menadione on DBTRG.05MG human glioma cells

The relative lack of inhibition by menadione on ongoing DNA synthesis in adult normal rat cerebral cortex suggested that the drug might be useful as anticancer drugs for brain tumors in adults because of potential lower toxicity to normal cells. In an adult animal model of glioma, we previously showed that the ongoing DNA synthesis rate was relatively high in tumor tissue compared to normal brain tissue [17]. Unfortunately, the tissue mini-unit system does not allow the study of prolonged drug incubation time. For this reason we next evaluated the anti-proliferative effect of menadione on the human DBTRG.05MG glioma cells using a standard short term $(72 \mathrm{~h})$ proliferation assay. Since menadione effect might be serum dependent we performed concentration- responses experiments in serum-free as well as serum-containing media. Menadione alone inhibits cell proliferation with similar efficiency in both media (data not shown). Vitamin $\mathrm{C}$ alone in the range 0.1-5 $\mathrm{mM}$ slightly inhibited cell proliferation and the combination of both drugs in the ratio 1:100 (e.g. menadione $1 \mu \mathrm{M}+$ Vitamin $\mathrm{C} 0.1 \mathrm{M}$ ) showed modest increase in potency compared to menadione alone (Fig. 2).

In order to evaluate the effect of long term incubation of these drugs, DBTRG.05MG cells were incubated with different concentrations of each drug alone or in combination for 2 weeks as described in Materials and Methods and the $\mathrm{RC}_{0}$ parameter was determined. Menadione $(1-25 \mu \mathrm{M})$ alone or vitamin $\mathrm{C}$ alone $(0.1-2.5 \mathrm{mM})$ failed to kill $100 \%$ of glioma cells: a small fraction of cells survived up to 1 week exposure and were able to resume growth when cells were cultured in drug-free media (Fig. 3 Top). To prevent regrowth of DBTRG.05MG cells, menadione at $50 \mu \mathrm{M}$ for one week (Fig. 3 Middle) or $25 \mu \mathrm{M}$ for 2 weeks (data not shown) were required. Vitamin $\mathrm{C}$ alone failed to prevent regrowth unless a very high concentration $(>5 \mathrm{mM})$ for 1 week was used (Fig. 3 Top and Middle). When used in combination at relatively low doses (M:VC at $10 \mu \mathrm{M}: 1 \mathrm{mM}$ ) for one week M:VC was able to prevent regrowth (Fig. 3 Bottom). Thus, the M:VC combination is a "pankiller" being able to prevent regrowth of glioma cells when the drug is removed from the media.

\section{Menadione:vitamin C (10 $\mu \mathrm{M}: 1 \mathrm{mM})$ shows similar antiproliferative activity in a panel of 8 patient derived cell cultures}

In order to evaluate the possibility that menadione:vitamin C might show differential potency for other glioma cells, we investigated the effect of selected drug treatment in a panel of 8 different patient derived cell cultures (hGCL1-8, Table 1$)$. Short term assays $(72 \mathrm{~h})$ showed modest or no difference between menadione alone and menadione +vitamin C. In long-term proliferation assays, despite the fact that some glioma cells were slightly resistant to menadione alone (e.g. few live cells were present after 2 weeks of menadione treatment with $25-50 \mu \mathrm{M})$ the M: $\mathrm{VC}$ combination for 1 week $(10 \mu \mathrm{M}: 1 \mathrm{mM})$ was able to prevent the regrowth of all cell cultures when the drug was removed from the culture (Table 1).

\section{Discussion}

In the present study, we first showed an age-dependent inhibitory effect of menadione on normal rat cerebral cortex (Fig. 1) suggesting that menadione might preferentially kill 

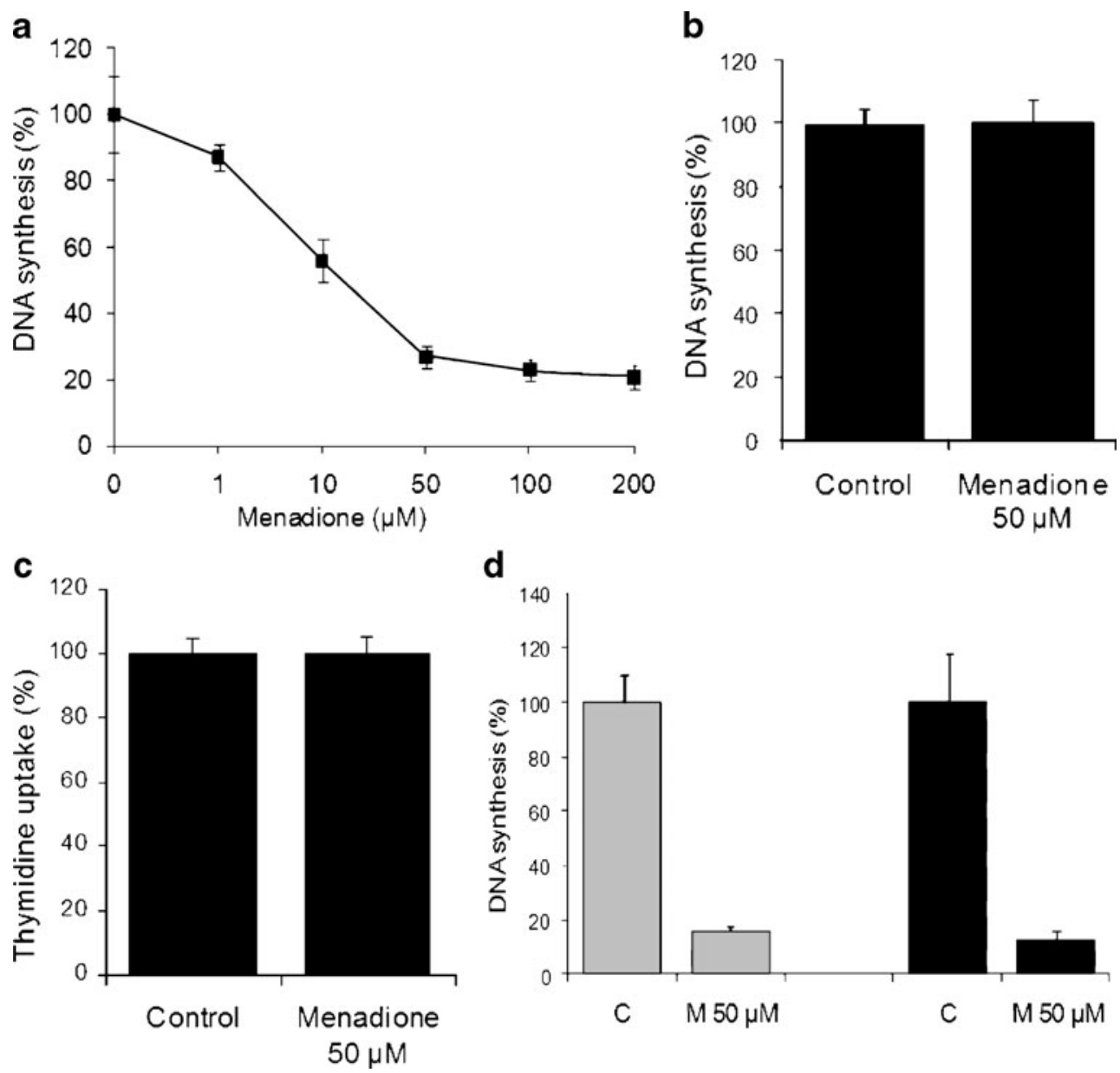

d

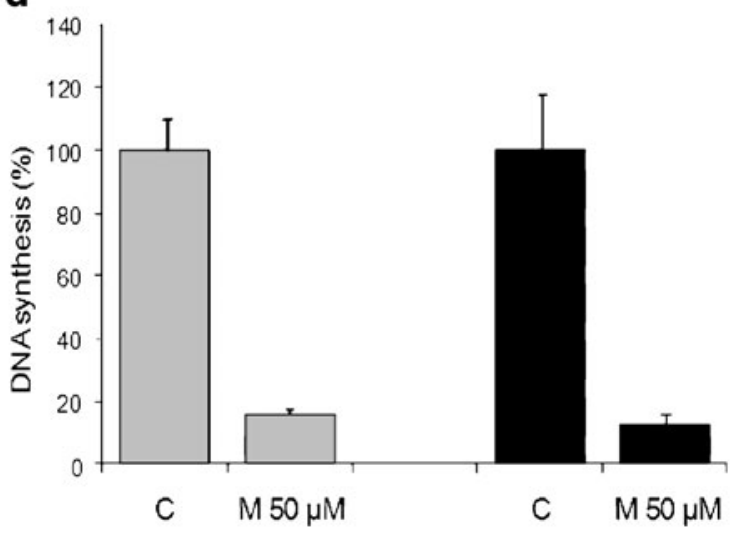

Fig. 1 Age-dependent inhibitory effect of menadione on normal rat cerebral cortex. a Concentration-dependent effect of menadione on DNA synthesis in tissue mini-units prepared from 5 days old rat cerebral cortex. b Effect of menadione $(50 \mu \mathrm{M})$ on DNA synthesis in tissue mini-units prepared from $>60$ days postnatal rat cerebral cortex. Control mini-units (expressed as: 100\% DNA synthesis) were incubated with equivalent concentrations of vehicle $(0.2 \%$ DMSO). $\mathbf{c}$ Effect of menadione on $\left[\right.$ methyl- $\left.{ }^{3} \mathrm{H}\right]$-thymidine uptake. The tissue mini-units prepared from the cerebral cortex from 5 days postnatal age rats were incubated with $50 \mu \mathrm{M}$ menadione or equivalent concentration of DMSO. After 60 min [methyl- $\left.{ }^{3} \mathrm{H}\right]$-thymidine (final concentration $4 \mu \mathrm{Ci} / \mathrm{ml}$ ) was added to each well, incubated for $15 \mathrm{~min}$ and the

fast proliferating cells. Since glioma mostly occurs in the adult population where menadione toxicity to normal tissue might be low, menadione can be exploited to kill fast proliferating tumor cells with relatively low toxicity to slow proliferating normal cells. Indeed, while $50 \mu \mathrm{M}$ menadione showed no effect on ongoing DNA replication in adult normal rat cerebral cortex (Fig. 1), the $\mathrm{IC}_{50}$ for the human DBTRG.05MG glioma line and patient-derived glioma cells was in the 10-25 $\mu \mathrm{M}$ range (Figs. 2 and 4). In our study, the data obtained from the tissue mini-unit system and the cell lines cannot be compared because they are different experimental systems and different exposure times were used. However, several groups had reported that low amount of radioactivity incorporated into the cell was determined as described in Materials and Methods. d Reversibility of menadionemediated DNA synthesis inhibition. Mini-units were incubated with DMSO alone $(\mathrm{C})$ or menadione $50 \mu \mathrm{M}(\mathrm{M})$ for 60 min with DMEM containing $4 \mu \mathrm{Ci} / \mathrm{ml}$ [methyl- $\left.{ }^{3} \mathrm{H}\right]$-thymidine (grey columns) or without [methyl- ${ }^{3} \mathrm{H}$ ]-thymidine (black columns). After incubation, the samples were processed for measurement of [methyl- $\left.{ }^{3} \mathrm{H}\right]$-thymidine incorporation into DNA (grey columns) or washed, incubated with DMEM containing $4 \mu \mathrm{Ci} / \mathrm{ml}\left[\right.$ methyl- $\left.{ }^{3} \mathrm{H}\right]$-thymidine for $90 \mathrm{~min}$ and then processed for measurement of $\left[\right.$ methyl- $\left.{ }^{3} \mathrm{H}\right]$-thymidine incorporation into DNA (black columns). All data are the results (mean \pm SEM) of 23 independent experiments performed by quadruplicate

menadione concentration $(10-50 \mu \mathrm{M})$ are relatively well tolerated by normal glial cells $[18,19]$. The tissue mini-unit system preserves the metabolic and proliferative properties of the tissue in situ and thus, suggests that menadione might be also less toxic for other neural cell types on adult tissue compared to young brain tissue. The early effect of menadione on ongoing DNA replication was irreversible (Fig. 1d), suggesting that the drug does not need to be continuously present to exert its anti-proliferative effect. Before clinical trials, toxicity to other normal neural cell types (neurons and neural stem cells) should be evaluated. Unfortunately, the tissue mini-unit system does not allow the evaluation of prolonged drug exposure and our assay 


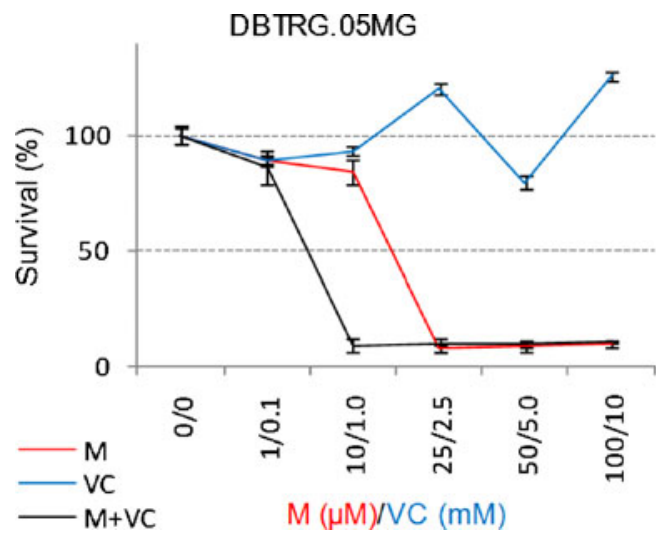

Fig. 2 Anti-proliferative effect of short term incubation with menadione (M), vitamin $\mathrm{C}(\mathrm{VC})$ and menadione:vitamin $\mathrm{C}(\mathrm{M}+\mathrm{VC})$. DBTRG-05MG glioma cells were incubated with the indicated concentration of drugs for $72 \mathrm{~h}$. Cell proliferation was measured by the CCK kit. Results are representative of two independent experiments performed by quadruplicates

did not measure viability of non-proliferating cells (e.g. neurons). On the other hand, even if available, studies on cell lines representing each neural cell type will not solve this problem since they are no representative of intact tissue due to loss of cell-cell interactions. Future studies on animal models are needed to address these important issues about toxicity. Regardless of this issue, strategies to potentiate the anti-proliferative effect of low menadione concentrations might help to selectively kill tumor cells. In this context, the combination of menadione+vitamin $\mathrm{C}$ has been explored in several cancer cell lines with encouraging results since this combination seems to selectively kill cancer cells by a novel mechanism of cell death called autoschizis $[20$, 21]. The cell injury of the menadione+vitamin $C$ has been associated with oxidative stress that affect the cytoeskeletal architecture [22]. Additional DNA damage might be caused by reactivation of DNAse activity that has been found to be negative in malignant tumors of the central nervous system $[22,23]$. The anti-proliferative effect of menadione has been studied in several glioma cell lines and showed $\mathrm{IC}_{50}$ values ranging between $13.5 \mu \mathrm{M}$ to $\sim 25 \mu \mathrm{M}[1,24]$. We recently suggested that drug concentrations much higher than the $\mathrm{IC}_{50}$ might be required to eliminate $100 \%$ of tumor cells and that the $\mathrm{IC}_{50}$ is not the best parameter to evaluate anti-cancer drugs because it does not select for useful clinical drugs [14].

In our study, the $\mathrm{IC}_{50}$ for the DBTRG.05MG human cell line and other patient derived cells hGCL1-8 were around $10-25 \mu \mathrm{M}$ but at least one week exposure to $50 \mu \mathrm{M}$ menadione alone was necessary to prevent regrowth of surviving cells. Increasing menadione concentration will
Fig. 3 Menadione:vitamin C combination inhibit cell proliferation and prevent regrowth of human glioma cells at doses lower than individual drugs. Anti-proliferative effect of long -term incubation with menadione alone $(\mathrm{M})$, vitamin $\mathrm{C}$ (VC) alone or Menadione:vitamin $\mathrm{C}$ at a 1:100 ratio. Top: Exponentially growing cells were incubated in complete media for 2-3 days $(a)$, exposed to 1-25 $\mu \mathrm{M}$ menadione or 0.1-2.5 mM vitamin $\mathrm{C}$ for 1 week $(b-c)$. During this period the media and the drugs were changed twice a week. A clear decrease in the cell density was observed by microscopic examination indicating extensive cell death $(b)$ followed by a stable low cell density $(c)$. When the drug was removed, the surviving cells resumed proliferation and formed a monolayer indicated as regrowth $(d)$. Middle: same as top but cells were incubated with menadione $50 \mu \mathrm{M}$ or vitamin $\mathrm{C}$ $5 \mathrm{mM}$ for 1 week. Bottom: same as top but cells were incubated with menadione $10 \mu \mathrm{M}+$ vitamin C $1 \mathrm{mM}$ for 1 week

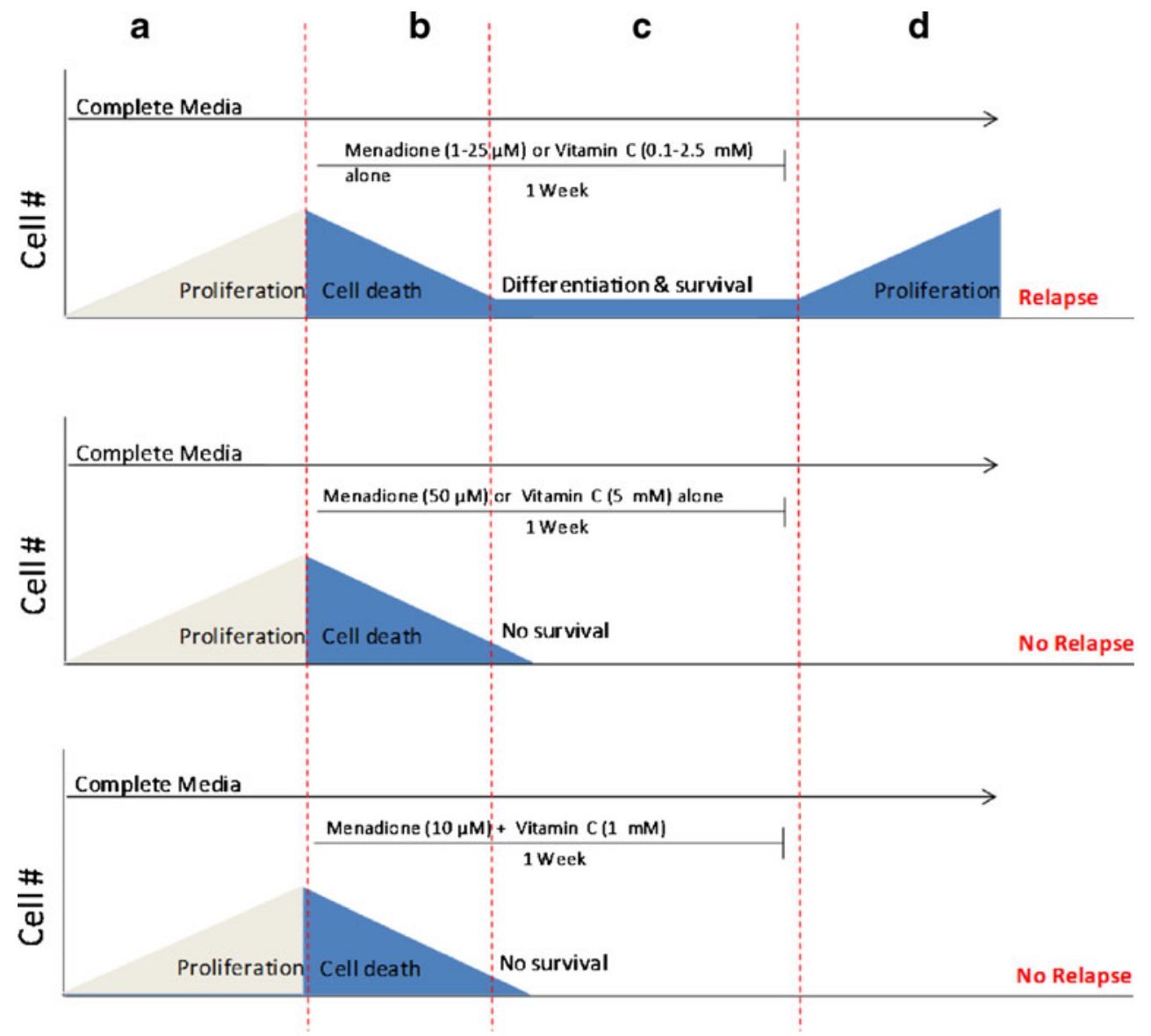


Table 1 Regrowth of glioma cells after prolonged treatment with Menadione (M), vitamin C (VC) or Menadione + Vitamin C (M:VC). Exponentially growing cells were incubated in complete media for $2-$ 3 days, exposed to the indicated concentration of menadione, vitamin
$\mathrm{C}$ or menadione:Vitamin $\mathrm{C}$ for 1 week and evaluated for regrowth after incubation in drug-free media for 2-4 weeks. $(+)$ and $(-)$ indicates ability to resume growth when the drug was removed from the culture media

\begin{tabular}{|c|c|c|c|c|c|c|c|c|c|}
\hline & & hGCL1 & hGCL2 & hGCL3 & hGCL4 & hGCL5 & hGCL6 & hGCL7 & hGCL8 \\
\hline \multirow[t]{2}{*}{$\mathrm{M}(\mu \mathrm{M})$} & 10 & + & + & + & + & + & + & + & + \\
\hline & 25 & $+^{\mathrm{a}}$ & - & $+^{\mathrm{a}}$ & - & - & $+^{\mathrm{a}}$ & - & - \\
\hline \multirow[t]{2}{*}{$\mathrm{VC}(\mathrm{mM})$} & 0.1 & + & + & + & + & + & + & + & + \\
\hline & 2.5 & + & + & + & + & + & + & + & + \\
\hline $\mathrm{M}: \mathrm{VC}(\mu \mathrm{M}: \mathrm{mM})$ & $10: 1$ & - & - & - & - & - & - & - & - \\
\hline $\mathrm{M}: \mathrm{VC}(\mu \mathrm{M}: \mathrm{mM})$ & $25: 2.5$ & - & - & - & - & - & - & - & - \\
\hline
\end{tabular}

${ }^{\mathrm{a}}$ Few cells were observed

also increase toxicity to normal cells. To circumvent this problem, combination with other drugs might selectively kill cancer cells without increasing toxicity to normal cells. In the present study, the addition of vitamin $C$ at a 1:100 ratio showed that it is possible to reduce the concentration of menadione needed to kill $100 \%$ of glioma cells from $25-$ $50 \mu \mathrm{M}$ to $10 \mu \mathrm{M}$. The combination also reduced the vitamin $\mathrm{C}$ concentration needed to kill $100 \%$ of glioma cells from 5 to $1 \mathrm{mM}$. Thus, this combination exhibited anti-tumor activity (cytotoxicity) at concentrations that were 2.5- to 5-fold lower than for the individual drugs. As suggested by Matzno et al. [25], the use of lower menadione concentration is advantageous because it makes easier to control the useful therapeutic range below toxic values due to the steepness of the concentration-response curve (Figs. 2 and 4). In agreement with the literature, antitumor activity at concentrations that were 4- to 61-fold lower than for the individual vitamins was found in other types of cancer [26]. However, results from our present data and those reported should be carefully evaluated considering methods and experimental designs. For instance, our values between 2 to 5 -fold lower were obtained measuring regrowth concentration zero $\left(\mathrm{RC}_{0}\right)$ as endpoint parameter while the reported values of 4- to 61 -fold values were

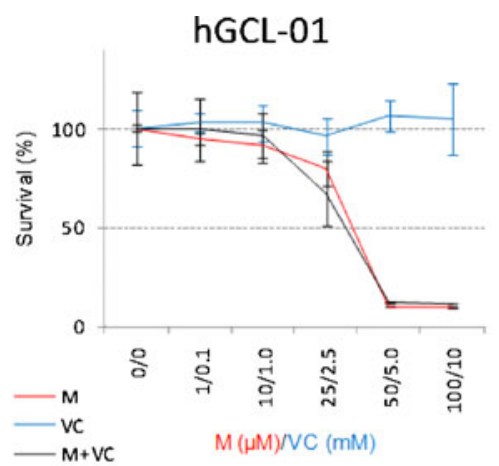

hGCL-05

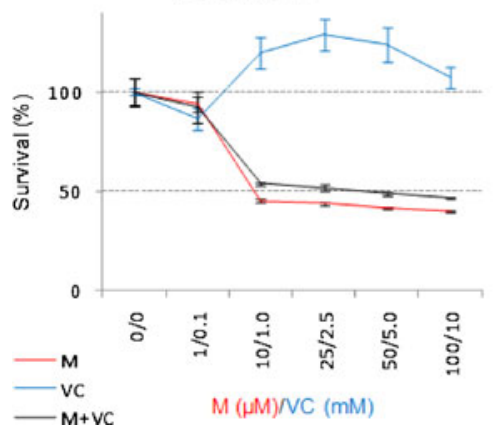

Fig. 4 Menadione alone and menadione:vitamin $\mathrm{C}$ showed similar anti-proliferative potency in a panel of 8 different patients derived glioma cells. Anti-proliferative effect of short term incubation with menadione alone $(\mathrm{M})$, vitamin $\mathrm{C}(\mathrm{VC})$ alone or menadione:vitamin $\mathrm{C}$
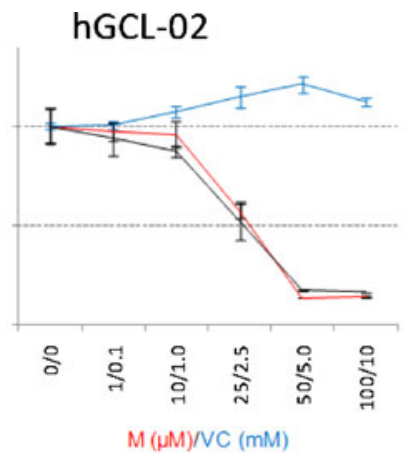

hGCL-06

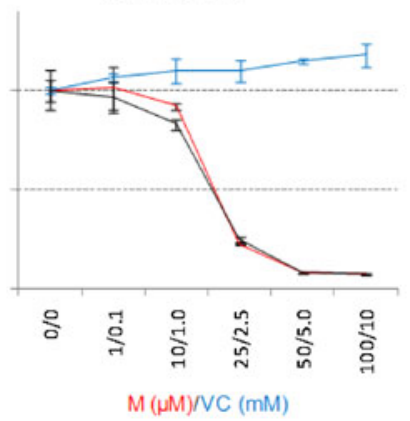

hGCL-03

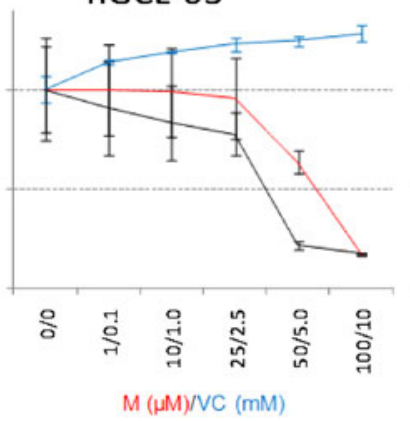

hGCL-07

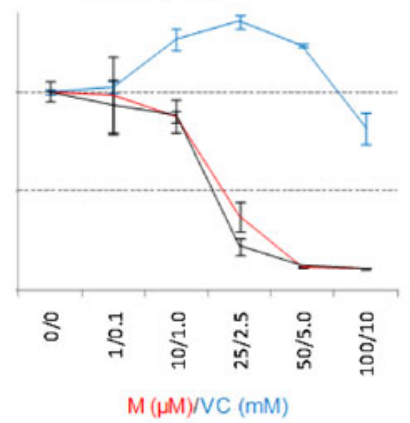

\section{hGCL-04}

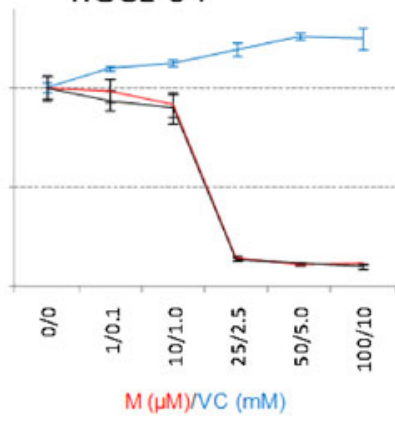

hGCL-08

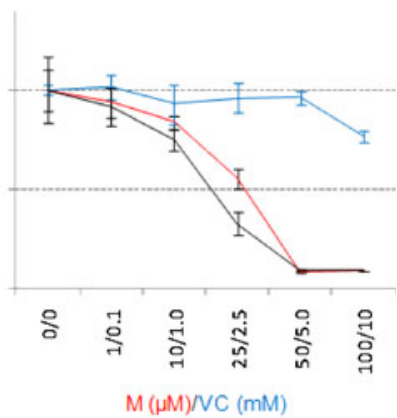

at a 1:100 ratio. hGCL1-8 cells were incubated with the indicated concentration of drugs for $72 \mathrm{~h}$. Cell proliferation was measured by the CCK kit 
obtained by determination of $\mathrm{CD}_{50}$ values by the MTT assay following $1 \mathrm{~h}$ treatment [27]. When 5 days continuous exposure was used, a lower synergistic effect (between 6 to 7 fold lower) was obtained [27]. It is possible that the $\mathrm{RC}_{0}$ may be similar for most cancer cells and only 2.5 to 5 -fold reduction can be obtained for each drug. Due to the heterogeneous nature of gliomas, the evaluation of several cell lines is important since some cell lines might show different sensitivity to a particular drug as it has been reported for temozolomide [28]. In conclusion, the menadione:vitamin $\mathrm{C}$ combination at $10 \mu \mathrm{M}: 1 \mathrm{mM}$ may be more selective against glioma cells and less toxic for normal brain tissue and should be a strong argument to encourage animal studies in order to evaluate the anti-proliferative effect on glioma models in addition to the overall systemic toxicity.

Acknowledgements This study was supported by grants from the Swedish Research Council and the Karolinska Institute. We thank Dr Peter Siesjö for providing the patient derived cells (hGCL1-8).

Open Access This article is distributed under the terms of the Creative Commons Attribution Noncommercial License which permits any noncommercial use, distribution, and reproduction in any medium, provided the original author(s) and source are credited.

\section{References}

1. Prasad KN, Edwards-Prasad J, Sakamoto A (1981) Vitamin K3 (menadione) inhibits the growth of mammalian tumor cells in culture. Life Sci 29:1387-1392

2. Taper HS, Keyeux A, Roberfroid M (1996) Potentiation of radiotherapy by nontoxic pretreatment with combined vitamins $\mathrm{C}$ and $\mathrm{K} 3$ in mice bearing solid transplantable tumor. Anticancer Res 16:499-504

3. Sun LK, Yoshii Y, Miyagi K (2000) Cytotoxic effect through Fas/ APO-1 expression due to Vitamin $\mathrm{K}$ in human glioma cells. J Neurooncol 47:31-38

4. Nishikawa Y, Carr BJ, Wang M, Kar S, Finn F, Dowd P, Zheng ZB, Kerns J, Naganathan S (1995) Growth inhibition of hepatoma cells induced by vitamin $\mathrm{K}$ and its analogs. J Biol Chem 270:28304-28310

5. Venugopal M, Jamison MJ, Gilloteaux J, Koch JA, Summers M, Giammar D, Sowick C, Summers JL (1996) Synergistic antitumor activity of vitamins $\mathrm{C}$ and $\mathrm{K} 3$ on human urologic tumor cell lines. Life Sci 59:1389-1400

6. Liao WC, Wu FY, Wu WC (2000) Binary/ternary combined effects of vitamin $\mathrm{K} 3$ with other antitumor agents in nasopharyngeal carcinoma CG1 cells. Int J Oncol 17:323-328

7. Chen AY, Liu LF (1994) Mechanisms of resistance to topoisomerase inhibitors. Cancer Treat Res 73:263-281

8. Okayasu H, Ishihara M, Satoh K, Sakagami H (2001) Cytotoxic activity of vitamins $\mathrm{K} 1, \mathrm{~K} 2$ and $\mathrm{K} 3$ against human oral tumor cell lines. Anticancer Res 21:2387-2392

9. Chung SH, Chung SM, Lee JY, Kim SR, Park KS, Chung JH (1999) The biological significance of non-enzymatic reaction of menadione with plasma thiols: enhancement of menadioneinduced cytotoxicity to platelets by the presence of blood plasma. FEBS Lett 449:235-240

10. Chen AY, Yu C, Lee WH, Peng LF, Liu LF (1992) Menadione (vitamin K3) induces topoisomerase II-mediated DNA cleavage. Proc Am Assoc Cancer Res 33:2588
11. Sasaki R, Suzuki Y, Yonezawa Y, Ota Y, Okamoto Y, Demizu Y, Huang P, Yoshida H, Sugimura K, Mizushina Y (2008) DNA polymerase gamma inhibition by vitamin $\mathrm{K} 3$ induces mitochondriamediated cytotoxicity in human cancer cells. Cancer Sci 99:1040 1048

12. Acharya BR, Choudhury D, Das A, Chakrabarti G (2009) Vitamin K3 disrupts the microtubule networks by binding to tubulin: a novel mechanism of its antiproliferative activity. Biochemistry 48:6963-6974

13. Pardridge WM (1998) CNS drug design based on principles of blood-brain barrier transport. J Neurochem 70:1781-1792

14. Avramidis D, Cruz M, Sidén Å, Tasat DR, Yakisich JS (2009) Regrowth concentration zero ( $\mathrm{RC} 0)$ as complementary endpoint parameter to evaluate compound candidates during preclinical drug development for cancer treatment. J Canc Sci Ther 1:19-24

15. Yakisich JS, Sidén Å, Idoyaga Vargas V, Eneroth P, Cruz M (1998) Fast and sensitive method for simultaneous measurement of cell proliferation rate and drug sensitivity in rat cerebral cortex. Exp Neurol 151:194-202

16. Yakisich JS, Sidén Å, Idoyaga Vargas V, Eneroth P, Cruz M (1999) Early effects of protein kinase modulator on DNA synthesis in rat cerebral cortex. Exp Neurol 159:164-176

17. Yakisich JS, Vita MF, Siden A, Tasat DR, Cruz M (2009) Strong inhibition of replicative DNA synthesis in the developing rat cerebral cortex and glioma cells by roscovitine. Invest New Drugs 28:299-305

18. Abe K, Saito H (1996) Menadione toxicity in cultured rat cortical astrocytes. Jpn J Pharmacol 72:299-306

19. Öztopcu-Vatan P, Kabadere S (2007) The effects of menadione on rat glial cell proliferation. J Neurol Sci (Turkish) 24:25-28

20. Gilloteaux J, Jamison JM, Lorimer HE, Jarjoura D, Taper HS, Calderon PB, Neal DR, Summers JL (2004) Autoschizis: a new form of cell death for human ovarian carcinoma cells following ascorbate:menadione treatment. Nuclear and DNA degradation. Tissue Cell 36:197-209

21. Gilloteaux J, Jamison JM, Neal DR, Summers JL (2005) Cell death by autoschizis in TRAMP prostate carcinoma cells as a result of treatment by ascorbate: menadione combination. Ultrastruct Pathol 29:221-235

22. Gilloteaux J, Jamison JM, Neal DR, Loukas M, Doberzstyn T, Summers JL (2010) Cell damage and death by autoschizis in human bladder (RT4) carcinoma cells resulting from treatment with ascorbate and menadione. Ultrastruct Pathol 34:140-160

23. Taper HS, Brucher JM, Fort L (1971) Activity of alkaline and acid nucleases in tumors of the human central nervous system. Histochemical study. Cancer 28:482-490

24. Oztopçu P, Kabadere S, Mercangoz A, Uyar R (2004) Comparison of vitamins $\mathrm{K} 1, \mathrm{~K} 2$ and $\mathrm{K} 3$ effects on growth of rat glioma and human glioblastoma multiforme cells in vitro. Acta Neurol Belg 104:106-110

25. Matzno S, Yamaguchi Y, Akiyoshi T, Nakabayashi T, Matsuyama $\mathrm{K}$ (2008) An attempt to evaluate the effect of vitamin K3 using as an enhancer of anticancer agents. Biol Pharm Bull 31:12701273

26. Gilloteaux J, Jamison JM, Arnold D, Neal DR, Summers JL (2006) Morphology and DNA degeneration during autoschizic cell death in bladder carcinoma T24 cells induced by ascorbate and menadione treatment. Anat Rec A Discov Mol Cell Evol Biol 288:58-83

27. Jamison JM, Gilloteaux J, Nassiri MR, Venugopal M, Neal DR, Summers JL (2004) Cell cycle arrest and autoschizis in a human bladder carcinoma cell line following Vitamin C and Vitamin K3 treatment. Biochem Pharmacol 67:337-351

28. Sankar A, Thomas DG, Darling JL (1999) Sensitivity of shortterm cultures derived from human malignant glioma to the anticancer drug temozolomide. Anticancer Drugs 10:179-185 